\title{
PHYSICOCHEMICAL CHARACTERISTICS, ANIMAL SPECIES DIVERSITY AND OXIDATIVE STRESS RESPONSES IN DOMINANT FISH FROM AN IMPACTED SITE ON THE LAGOS LAGOON, NIGERIA
}

\author{
Nwabueze, C. J. ${ }^{a}$, Sogbanmu, T. O. ${ }^{a} *$ and Ugwumba, A. A. A. \\ ${ }^{2}$ Ecotoxicology and Conservation Unit, Department of Zoology, Faculty of Science, \\ University of Lagos, Akoka 101017, Lagos, Nigeria. ${ }^{b}$ Department of Zoology, Faculty of Science, University of Ibadan, \\ Oyo State, Nigeria.*Corresponding author's email: tsogbanmu@unilag.edu.ng \\ (Received: $15^{\text {th }}$ March, 2020; Accepted: $14^{\text {th }}$ April, 2020)
}

ABSTRACT

\begin{abstract}
The evaluation of biomarkers in resident fisheries of aquatic ecosystems is important for risk assessment of such ecosystems. In this study, surface water and sediment physicochemical characteristics, macrobenthic invertebrate and fish species diversity and oxidative stress of dominant fish were evaluated at an anthropogenicimpacted site (Iddo) as well as a reference site (after the Third Mainland Bridge) of the Lagos lagoon, Nigeria, over a period of three (3) months. Surface water analysis result showed that the Total dissolved solids (TDS) $(5.54 \pm 2.85 \mathrm{mg} / \mathrm{L})$, Salinity $(5.09 \pm 2.56 \%$ oo $)$, Conductivity $(6.51 \pm 4.54 \mu \mathrm{S} / \mathrm{cm})$, Nitrates $(4.70 \pm 1.49 \mathrm{mg} / \mathrm{L})$, Phosphates $(3.03 \pm 0.60 \mathrm{mg} / \mathrm{L})$, Biochemical oxygen demand (BOD) $(18.62 \pm 3.77 \mathrm{mg} / \mathrm{L})$ and Chemical oxygen demand (COD) $(463.44 \pm 65.83 \mathrm{mg} / \mathrm{L})$ were significantly higher at the test site compared to the reference site. The COD of the sediment were significantly higher $(p<0.05)$ at the test site compared to the reference while the other sediment physicochemical parameters except $\mathrm{pH}$ were higher at the test site compared to the reference site. Macrobenthic invertebrate species diversity were slightly higher (1.70) at the reference site compared to the test site (1.66) while species richness were higher at the test site (1.43) compared to the reference site (1.26). Fish species diversity (1.95) and richness (1.79) were higher at the test site compared to the reference site. Dominant fish species at the test and reference sites were Ethmalosa fimbriata (Bonga shad) and Sarotherodon melanotheron (Blackchin Tilapia) respectively. There were increased levels of antioxidant enzymes and biomoleculesglutathione S-transferase (GST), superoxide dismutase (SOD), catalase (CAT), reduced glutathione (GSH) and malondialdehyde (MDA) in the gills and liver of E. fimbriata indicative of oxidative stress. Further studies on biomarkers at lower levels of biological organisation are recommended for holistic evaluations and evidencebased intervention if necessary. This will support the achievement of the United Nations Sustainable Development Goal 14 (life below water).
\end{abstract}

Keywords: Lagos lagoon; Animal species diversity; Oxidative stress indices; Dominant fish species; Sewage

\section{INTRODUCTION}

The Lagos lagoon is a coastal lagoon and one of the major lagoon ecosystems in Nigeria, which provides ecosystem services that supports resident organisms and the wellbeing of coastal populations by providing a source of food and employment (Alava et al., 2017). Due to the preponderance of anthropogenic activities around the coastlines, the water quality is deteriorating with adverse impacts on fisheries and coastal communities (Amaeze et al., 2012; Sogbanmu et al., 2019). These anthropogenic activities include industrial effluent discharge, sawmilling activities, wood burning and transportation, petroleum tank farms, coastal solid waste dumpsites, shipping and port activities (Amaeze et al., 2012; Sogbanmu et al., 2019; 2020). Water quality guidelines provide basic scientific information about water quality parameters and ecologically relevant toxicological threshold values to protect specific water uses (Lawson, 2011).

Physical and chemical parameters influence the aquatic environment affecting the survival and abundance of aquatic fauna and flora (Kane et al., 2015). Temperature, pH, salinity, dissolved oxygen, total dissolved solids (TDS), and nutrients are examples of some of these physical and chemical parameters. Sediments provides habitat for various species of animals in the aquatic ecosystem and acts as a sink particularly for organic contaminants released into water bodies (Sogbanmu et al., 2020). The level of anthropogenic enrichment of a water body with nutrients strongly influences its organism spectrum in terms of the composition, distribution and abundance (Alexander et al., 
082 Nwabueze et al.: Physicochemical Characteristics, Animal Species Diversity and Oxidative Stress Responses

2017). Biodiversity is thus a good bio-monitor for assessing the health status of organisms in the aquatic ecosystem (Olaniran et al., 2019). The Lagos lagoon has been used as a dump for waste materials which has reduced the annual fish production (Singh et al., 1995). This is due to the enrichment of lagoon with various contaminants ranging from biodegradable matter, nutrients, toxic and other substances which perturb the natural ecological equilibrium, therefore altering biodiversity (Emmanuel et al., 2010).

The effects of pollutants on aquatic fauna can be assessed at different levels of biological organisation using biomarkers (Sogbanmu et al., 2018). All biological systems generate endogenous reactive oxygen species (ROS) during their aerobic metabolism and energy production (ATP generation) in the mitochondria (Buege and Aust, 1978). Some pollutants have the potential to produce ROS in organisms which are exposed to them, thereby causing an increase in the level of ROS in the body of the organisms (Birben et al., 2012). An organism's defence systems of enzymatic and non-enzymatic anti-oxidants help to reduce the presence of ROS within the organisms. Enzymatic antioxidant defences of living systems include: superoxide dismutase (SOD), catalase (CAT), glutathione peroxidase $(\mathrm{GPx})$, glutathione reductase $(\mathrm{GRx})$ and glutathione S-transferase (GST). An increase in the activity of these enzymes is an indication (biomarker) of the effect of pollutants that generate ROS (Sogbanmu et al., 2018). Lipid peroxidation is also a biomarker of oxidative damage in organisms inhabiting polluted ecosystems. It is generated by free radicals in an organism. An increase in free radicals causes over production of malondialdehyde (MDA) which is one of the final products of polyunsaturated fatty acids peroxidation in the cells of organisms (Buege and Aust, 1978). The Iddo part of the Lagos lagoon, for decades, has been a disposal site for raw faecal sewage. This study aims to assess the surface water and sediment quality, animal species diversity as well as oxidative stress indices in dominant fishes at Iddo site and a reference site on the Lagos lagoon, Nigeria.

\section{MATERIALS AND METHODS}

\section{Study Area and Sampling Techniques of} Surface Water and Sediments

The study area was the Lagos lagoon with test and the reference sites at Iddo $\left(06^{\circ} 28^{\prime} 23.05^{\prime \prime} \mathrm{N}\right.$ to $03^{\circ}$ 23' 38.83' E) and After the Third Mainland Bridge (ATMB) $\left(06^{\circ} 30^{\prime} 57.19^{\prime \prime} \mathrm{N}\right.$ to $\left.03^{\circ} 24^{\prime} 20.81^{\prime \prime} \mathrm{E}\right)$ (Figure 1). Six sampling stations were selected for this study, with three (3) sampling stations at the test site (Iddo) and the other three (3) at the reference site (ATMB), a relatively uncontaminated area. The sampling stations were georeferenced with a Google Map Global Positioning System (GPS), permanent and semipermanent structures were noted and used in marking sampling locations. Sampling was conducted in the wet season for three (3) months (July-September 2018).

\section{Analysis of Surface Water and Sediment Samples from the Lagos Lagoon}

Physico-chemical analysis of water was carried out in-situ for the following parameters: temperature, $\mathrm{pH}$, salinity, conductivity, dissolved oxygen, total dissolved solids and turbidity using a multi-meter water checker (Horiba U-10). Surface water at the sampling stations was collected at a depth of $10 \mathrm{~cm}$ for laboratory analyses and was labelled immediately on the field. Surface water samples were collected in amber bottles and preserved with a drop of sulphuric acid for the evaluation of Biochemical Oxygen Demand (BOD), Chemical Oxygen Demand (COD), phosphates and nitrates following standard procedures. Sediment samples from each sampling station were collected with the use of Van-Veen grab, put into labelled aluminum foil and transported to the laboratory for estimation of the physicochemical parameters (Sogbanmu et al., 2020). 


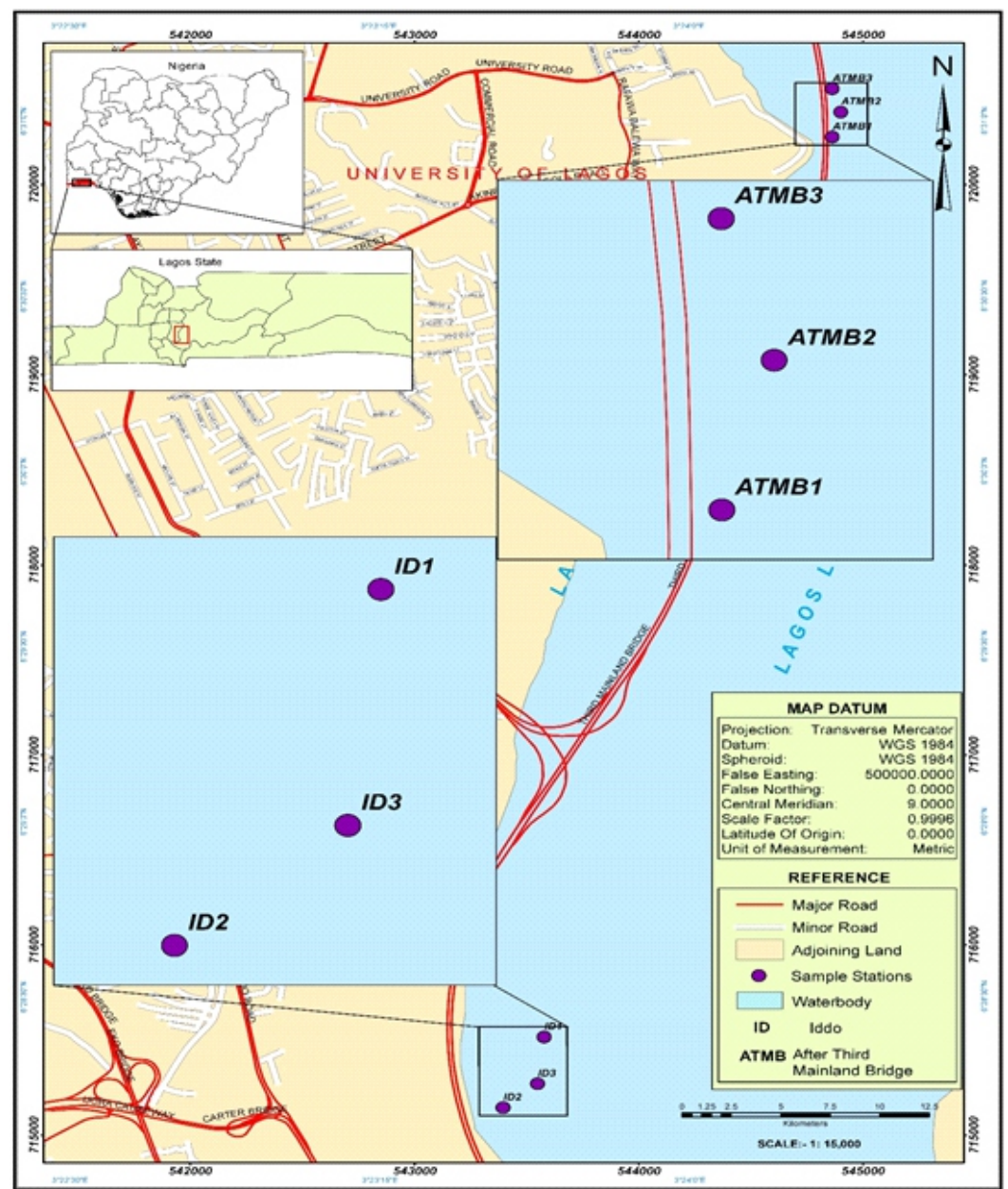

Figure 1: Map of the Lagos Lagoon showing the Sampling Points (ID - Iddo; ATMB - After Third Mainland Bridge)

Sampling of Macrobenthic Invertebrates and Fishes for Species Diversity Studies

Macrobenthic invertebrates were collected concurrently using a Van-Veen grab (Olaniran et al., 2019). At each study station, two grab hauls were sieved using a stainless-steel sieve (mesh size - $0.32 \mu \mathrm{m})$ and the macrobenthic invertebrates sieved out were placed in a pre-labelled plastic container with cover, and then preserved with 10\% formalin (Nkwoji, 2016). The macrobenthic invertebrates were identified to species level where possible, counted and their numbers recorded. Identification was done after Yankson and Kendall (2001).

The fishes were procured from the fishermen that were fishing at the test and reference sampling sites on the lagoon on a monthly basis. The sampling gears used for fishing by the fishermen included basket traps, baited long lines and set gill net (Ajabge et al., 2012). The fish samples were transported in a cooler with ice-cubes to
University of Lagos, Zoology Laboratory for identification and tissue extraction.

\section{Oxidative Stress Evaluations of Dominant Fish from Sampling Stations on the Lagos Lagoon}

The collection and handling of the fishes were in line with international ethical standards (AVMA, 2013). Three (3) dominant fishes were selected from the test and reference sites each. Upon euthanization, the fishes were dissected through the ventral side and the liver and gills were extracted. The extracted gills and liver were placed in pre-labelled universal bottles, sealed and stored in the freezer at $-18{ }^{\circ} \mathrm{C}$. The tissues of the fishes were washed in an ice cold $1.15 \% \mathrm{KCl}$ solution, blotted and weighed. They were then homogenized in $0.1 \mathrm{M}$ phosphate buffer ( $\mathrm{pH} 7.2)$, and transferred into a laboratory mortar; laboratory sand was added to it (acid washed sand) and further homogenized with laboratory mortar and pestle. The resulting homogenate was 
084 Nwabueze et al.: Physicochemical Characteristics, Animal Species Diversity and Oxidative Stress Responses

centrifuged at $2500 \mathrm{rpm}$ for 15 mins. The supernatant was decanted and stored at $-20{ }^{\circ} \mathrm{C}$ until analysis for spectrophotometric estimation of antioxidant activities: catalase (CAT), superoxide dismutase (SOD), reduced glutathione (GSH), malondialdehyde (MDA) and glutathioneS-transferase (GST).

Malondialdehyde (MDA), a by-product of lipid peroxidation was determined using the method of Buege and Aust (1978). $1.0 \mathrm{ml}$ of the supernatant was added to $2 \mathrm{ml}$ of (1:1:1 ratio) TCA-TBA-HCl reagent (thiobarbituric acid $0.37 \%, 0.24 \mathrm{~N} \mathrm{HCl}$ and 15\% TCA) trichloroacetic acid-thiobarbituric acid-hydrochloric acid reagent boiled at $100{ }^{\circ} \mathrm{C}$ for $15 \mathrm{~min}$, and allowed to cool. Flocculent materials were removed by centrifuging at $3000 \mathrm{rpm}$ for 10 min. The supernatant was removed and the absorbance read at $532 \mathrm{~nm}$ against a blank. MDA was calculated using the molar extinction coefficient of $1.56 \times 10^{5} \mathrm{M}^{-1} \mathrm{~cm}^{-1}$.

Superoxide dismutase (SOD) activity was determined by measuring the inhibition of autooxidation of epinephrine at $\mathrm{pH} 10.2$ at $30{ }^{\circ} \mathrm{C}$ as described by Magwere (1997). One unit of superoxide activity is the amount of SOD necessary to cause $50 \%$ inhibition of epinephrine auto-oxidation. The assay was performed in $3.0 \mathrm{ml}$ of $50 \mathrm{M} \mathrm{Na}_{2} \mathrm{CO}_{3}$ buffer to which $0.02 \mathrm{ml}$ of the tissue homogenate was added. $0.03 \mathrm{ml}$ of epinephrine stock solution was added before reading the absorbance at $480 \mathrm{~nm}$ for 3-5 mins.

Catalase (CAT) was assayed colorimetrically at 620 $\mathrm{nm}$ and expressed as $\mu \mathrm{M}$ of $\mathrm{H}_{2} \mathrm{O}_{2}$ consumed per min per $\mathrm{mg}$ protein at $25{ }^{\circ} \mathrm{C}$ (Sinha, 1972). The reaction mixture $(1.5 \mathrm{ml})$ contained $1.0 \mathrm{ml} 0.01 \mathrm{M}$ phosphate buffer ( $\mathrm{pH} 7.0), 0.1 \mathrm{ml}$ tissue homogenate extract and $0.4 \mathrm{ml} 2 \mathrm{M} \mathrm{H}_{2} \mathrm{O}_{2}$. The reaction was stopped by the addition of $2.0 \mathrm{ml}$ dichromate-acetic acid reagent $5 \%$ potassium dichromate and glacial acetic acid were mixed in 1:3 ratio). The unit of expression of CAT activity was $\mu \mathrm{mol} \mathrm{H}_{2} \mathrm{O}_{2}$ per min per mg protein.

The reduced glutathione (GSH) content of tissue as non-protein sulphydryls was estimated according to the method described by Sedlak and Lindsay (1968). To the homogenate, 10\% TCA was added and centrifuged. $1.0 \mathrm{ml}$ of supernatant was treated with $0.5 \mathrm{ml}$ of Ellman's reagent (19.8 $\mathrm{mg}$ of 5,5'-dithiobis-(2-nitrobenzoic acid) (DTNB) in $100 \mathrm{ml}$ of $0.1 \%$ sodium nitrate) and $3.0 \mathrm{ml}$ of phosphate buffer $(0.2 \mathrm{M}, \mathrm{pH} 8.0)$. The absorbance was read at $412 \mathrm{~nm}$.

Glutathione S-transferase (GST) activity was determined according to the method of Habig et al., (1974). This is based on the fact that almost all GSTs demonstrate a relatively high activity with 1chloro-2,4-dintrobenzene (CDNB) as the second substrate. Consequently, the conventional assay for GST activity utilizes 1-chloro-2,4dintrobenzene as substrate. When this substrate is conjugated with reduced glutathione (GSH), its absorption maximum shifts to a longer wavelength. The absorption increases at the new wavelength of $340 \mathrm{~nm}$ which provides a direct measurement of the enzymatic reaction. The medium for the estimation of GST activity was prepared and the reaction was allowed to run for 60 secs each time before the absorbance was read against the blank at $340 \mathrm{~nm}$. The temperature was maintained at approximately $31{ }^{\circ} \mathrm{C}$. The absorbance was measured using a spectrophotometer.

\section{Statistical Analysis}

The diversity of macrobenthic invertebrates and fishes were determined using diversity indices such as Margalef species richness index, $d$ (Margalef, 1951), Shannon-Wiener diversity index H, (Shannon and Weaver, 1949) and equitability using evenness index, E. The diversity indices were computed using a computer software package, 'PAST' (Hammer et al.2001).

For the oxidative stress parameters, significant differences between dominant fishes from the test and reference sites were evaluated using One Way Analysis of Variance (ANOVA) with SPSS version 20.0. Significant differences were set at $\mathrm{p}<0.05$.

\section{RESULTS}

\section{Anthropogenic Activities at the Test Site on the Lagos Lagoon}

Photographs of the study area on the Lagos lagoon showing some of the sources of pollution in the area are shown in plate 1. Anthropogenic activities observed at the Iddo sampling station 1 
$\left(06^{0} 28^{\prime} 23.05^{\prime \prime} \mathrm{N}, 03^{0} 23^{\prime} 38.83^{\prime \prime} \mathrm{E}\right)$ were fishing activities with motorized boats (diesel powered), solid waste dump (Plate 1a), public toilets channeled directly into the lagoon (Plate 1b) and direct defecation into the lagoon and saturated by foul smelling air, sewage tunnels channelled into the lagoon (Plate 1c) and sewage discharge point at the test site station 1 (Plate 1d). Test station 2 (06 $\left.{ }^{\circ} 28^{\prime} 10.93^{\prime \prime} \mathrm{N}, 03^{\circ} 23^{\prime} 32.83^{\prime \prime} \mathrm{E}\right)$ was characterized by direct defecation, fishing activities with motorized boat, a power station, solid waste dumps.
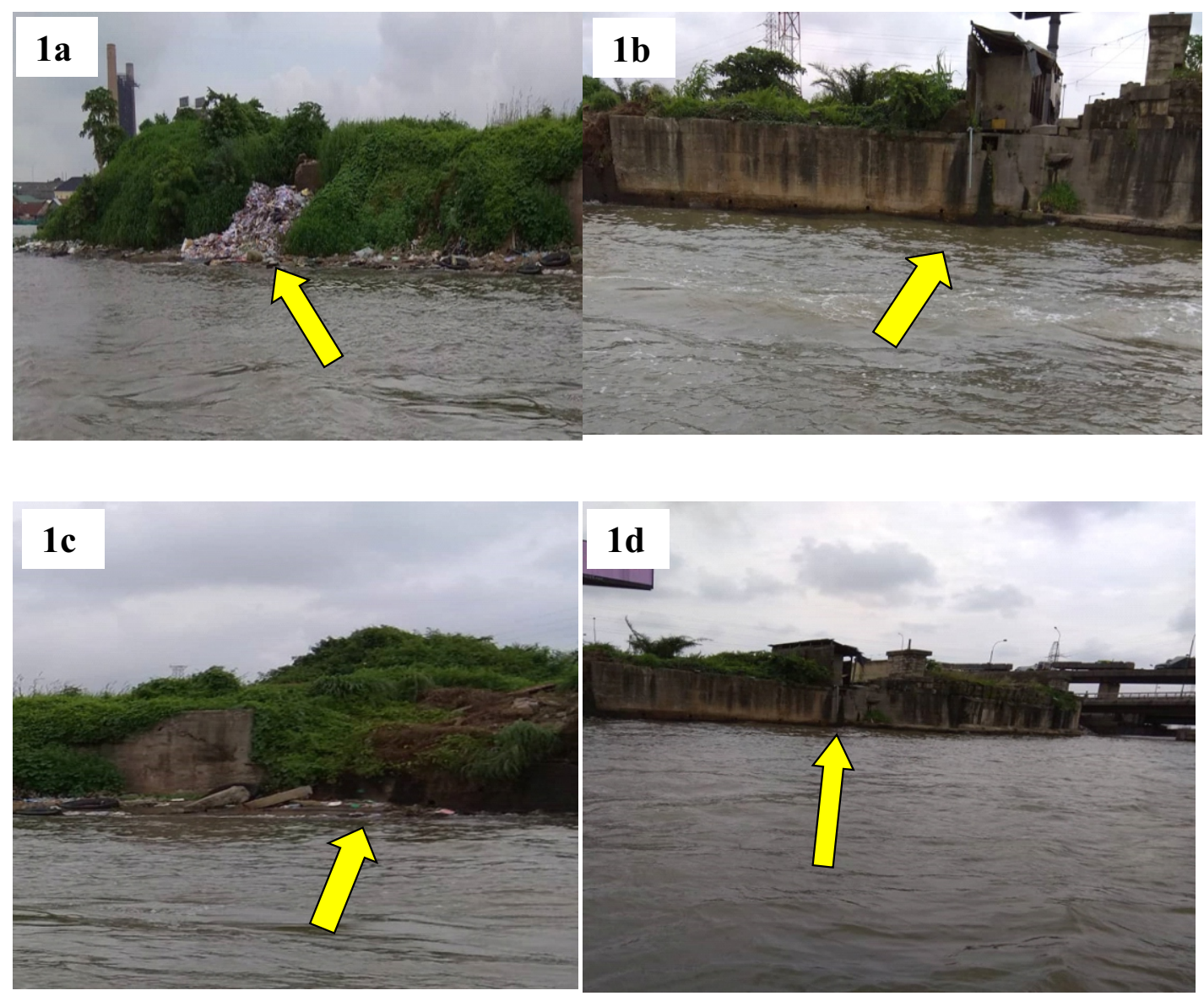

Plate 1a-d: Photographs of the Study Area on the Lagos lagoon.

Key: $1 \mathrm{a}$ - Solid waste dump site; $1 \mathrm{~b}$ - A public toilet which discharges directly into the lagoon; 1c - Sewage tunnels channelled into the lagoon; $1 \mathrm{~d}$ - Sewage discharge point at the test site

Physicochemical Parameters of Surface Water and Sediment at the Test and Reference Sites

The mean variations in the physicochemical parameters of surface water (Table 1) from the test sites showed that the Total Dissolved Solids $(5.54 \pm 2.85 \mathrm{mg} / \mathrm{L})$, salinity $(5.09 \pm 2.56 \% 0)$, conductivity $(6.51 \pm 4.54 \mu \mathrm{s} / \mathrm{cm})$, nitrates

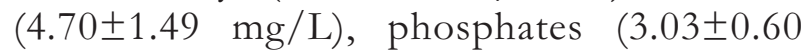
$\mathrm{mg} / \mathrm{L})$, BOD $(18.62 \pm 3.77 \mathrm{mg} / \mathrm{L})$ and COD $(463.44 \pm 65.83 \mathrm{mg} / \mathrm{L})$ were significantly higher than those of the reference sites. Other parameters such as temperature $\left(26.13 \pm 0.51{ }^{\circ} \mathrm{C}\right)$, $\mathrm{pH}(5.46 \pm 1.12)$ and dissolved oxygen (17.76 \pm 7.32 $\mathrm{mg} / \mathrm{L}$ ) were slightly higher at the test sites than the reference sites. Higher levels of turbidity were recorded for both the test $(74.10 \pm 77.70 \mathrm{NTU})$ and reference sites $(85.71 \pm 39.87$ NTU) (Table 1$)$.

Chemical oxygen demand was significantly higher $(p<0.05)$ at the test sites $(507.31 \pm 109.47 \mathrm{mg} / \mathrm{kg})$ compared to the reference sites $(315.14 \pm 234.39$ $\mathrm{mg} / \mathrm{kg}$ ) (Table 1). The other parameters ( $\mathrm{pH}$, total organic matter (TOM), salinity, conductivity, nitrates, phosphates and BOD) measured in sediments were higher at the test sites though not significant $(p>0.05)$ compared to the reference sites (Table 1). 
086 Nwabueze et al.: Physicochemical Characteristics, Animal Species Diversity and Oxidative Stress Responses

Table 1: Physicochemical Parameters of Surface Water from the Test and Reference Sites

\begin{tabular}{llll}
\hline \multicolumn{3}{c}{ SURFACE WATER } \\
\hline $\begin{array}{l}\text { Physicochemical } \\
\text { Parameters }\end{array}$ & Test site & Reference site & $\begin{array}{l}\text { FMENV 1991 } \\
\text { Limit }\end{array}$ \\
\hline Temperature $\left({ }^{\circ} \mathrm{C}\right)$ & $26.13 \pm 0.51$ & $26.10 \pm 0.66$ & $<40$ \\
$\mathrm{pH}$ & $5.46 \pm 1.12$ & $4.32 \pm 0.85$ & $6-9$ \\
Turbidity (NTU) & $74.10 \pm 77.70$ & $85.71 \pm 39.87$ & 10 \\
Dissolved oxygen (mg/L) & $17.76 \pm 7.32$ & $17.4 \pm 8.32$ & 5.0 \\
TDS (mg/L) & $5.54 \pm 2.85^{\mathrm{a}}$ & $1.34 \pm 0.94^{\mathrm{b}}$ & 2000 \\
Salinity $(\% / \mathrm{oo})$ & $5.09 \pm 2.56^{\mathrm{a}}$ & $0.72 \pm 0.69^{\mathrm{b}}$ & $\mathrm{NS}$ \\
Conductivity $(\mu \mathrm{S} / \mathrm{cm})$ & $6.51 \pm 4.54^{\mathrm{a}}$ & $1.64 \pm 1.21^{\mathrm{b}}$ & $\mathrm{NS}$ \\
Nitrates $(\mathrm{mg} / \mathrm{L})$ & $4.70 \pm 1.49^{\mathrm{a}}$ & $3.63 \pm 0.68^{\mathrm{b}}$ & 20 \\
Phosphates $(\mathrm{mg} / \mathrm{L})$ & $3.03 \pm 0.60^{\mathrm{a}}$ & $1.39 \pm 0.34^{\mathrm{b}}$ & 5 \\
BOD $(\mathrm{mg} / \mathrm{L})$ & $18.62 \pm 3.77^{\mathrm{a}}$ & $10.58 \pm 0.68^{\mathrm{b}}$ & 50 \\
COD $(\mathrm{mg} / \mathrm{L})$ & $463.44 \pm 65.83^{\mathrm{a}}$ & $277.11 \pm 28.87^{\mathrm{b}}$ & $\mathrm{NS}$ \\
\hline
\end{tabular}

\begin{tabular}{lllllll}
\hline & \multicolumn{3}{c}{ SEDIMENT } \\
\hline Parameter & \multicolumn{3}{c}{ Test site } & \multicolumn{4}{c}{ Reference site } \\
& Min & Max & Mean \pm SD & Min & Max & Mean \pm SD \\
\hline $\mathrm{pH}$ & 4.9 & 8.1 & $6.93 \pm 1.01$ & 4.8 & 8.4 & $6.73 \pm 1.41$ \\
TOM $(\mathrm{mg} / \mathrm{kg})$ & 81.09 & 93.36 & $88.10 \pm 4.26$ & 68.65 & 87.2 & $81.08 \pm 5.64$ \\
Salinity $(\% / \mathrm{oo})$ & 0.62 & 3.01 & $2.11 \pm 1.05$ & 0.35 & 3.79 & $2.01 \pm 1.13$ \\
Conductivity $(\mu \mathrm{s} / \mathrm{cm})$ & 1.64 & 7.9 & $4.40 \pm 2.61$ & 0.88 & 4.61 & $2.91 \pm 1.55$ \\
Nitrates $(\mathrm{mg} / \mathrm{kg})$ & 6.3 & 8.3 & $7.33 \pm 0.57$ & 4.84 & 6.9 & $6.10 \pm 0.72$ \\
Phosphates $(\mathrm{mg} / \mathrm{kg})$ & 3.09 & 4.23 & $3.61 \pm 0.43$ & 2.83 & 5.67 & $3.61 \pm 0.89$ \\
BOD $(\mathrm{mg} / \mathrm{kg})$ & 3.45 & 32.87 & $17.49 \pm 11.55$ & 2.09 & 26.93 & $14.23 \pm 10.71$ \\
COD $(\mathrm{mg} / \mathrm{kg})$ & 412 & 746.13 & $507.31 \pm 109.47^{\mathrm{a}}$ & 3.48 & 493.61 & $315.14 \pm 234.39^{\mathrm{b}}$ \\
\hline
\end{tabular}

The results are expressed as mean $\pm \mathrm{SD}, \mathrm{n}=3$. Dissimilar letters indicate significant difference of the parameter between the lagoons $(p<0.05)$. FMENV - Federal Ministry of Environment

Macrobenthic Invertebrate and Fish Species Diversity

A total of six (6) macrobenthic invertebrate species were identified in this study (Table 2). Three (3) of the species (Neritina glabrata, Tympanotonus fuscatus, Pachymelania aurita) were of the class Gastropoda and the other three (Mytilus edulis, Tellina nymphalis and Iphigenia truncata) were of the class Bivalvia. The reference site recorded higher species diversity (1.70) and species evenness (0.95) than the test site (1.66 and 0.93 respectively). Species richness was higher in the test site (1.43) than the reference site (1.26).
Photographs of some fishes identified in this study are shown in plate 2. A total of 262 fishes were recorded from the test and reference sites in this study (Table 2). Fish species abundance was higher at the test site (153 individuals comprising of 10 species), than the refence site (109 individuals comprising of 9 species) (Table 2 ). The fish population in the test site was dominated by Ethmalosa fimbriata of the family Clupidae, while the reference site was dominated by Sarotherodon melanotheron of the family Cichlidae (Plate 2a-f). Species richness (Margalef richness index) was higher at the test site (1.79) compared to the reference site (1.71) (Table 2) 
Nwabueze et al.: Physicochemical Characteristics, Animal Species Diversity and Oxidative Stress Responses

Table 2: Macrobenthic Invertebrate and Fish Species Diversity at the Test and Reference Sites on the Lagos lagoon, Nigeria

\begin{tabular}{|c|c|c|c|c|c|}
\hline Class & Family & Scientific Names & Common Names & $\begin{array}{l}\text { Test } \\
\text { site } \\
\text { (Iddo) }\end{array}$ & $\begin{array}{l}\text { Ref. site } \\
\text { (ATMB) }\end{array}$ \\
\hline \multicolumn{6}{|c|}{ MACROBENTHIC INVERTEBRATE SPECIES } \\
\hline \multirow[t]{3}{*}{ Gastropoda } & Neritidae & Neritina glabrata & Nerite snails & 1 & 5 \\
\hline & Potamididae & $\begin{array}{l}\text { Tympanotonus } \\
\text { fuscatus }\end{array}$ & $\begin{array}{l}\text { West African Mud } \\
\text { Creeper }\end{array}$ & 8 & 13 \\
\hline & Thiaridae & $\begin{array}{l}\text { Pachymelania } \\
\text { aurita }\end{array}$ & Periwinkle & 5 & 8 \\
\hline \multirow[t]{3}{*}{ Bivalvia } & Mytilidae & Mytilus edulis & Common blue mussel & 5 & 9 \\
\hline & Tellinidae & Tellina nymphalis & Soft shell clam & 9 & 14 \\
\hline & Donacidae & Iphigenia truncata & & 5 & 4 \\
\hline \multicolumn{4}{|c|}{ Specie Abundance } & 33 & 53 \\
\hline \multicolumn{4}{|c|}{ Specie variety } & 6 & 6 \\
\hline \multicolumn{4}{|c|}{ Simpson's index 1-D } & 0.80 & 0.80 \\
\hline \multicolumn{4}{|c|}{ Simpson's index 1-D } & 1.66 & 1.70 \\
\hline \multicolumn{4}{|c|}{ Evenness_e $e^{\wedge} \mathrm{H} / \mathrm{S}$} & 0.88 & 0.91 \\
\hline \multicolumn{4}{|c|}{ Margalef Richness index } & 1.43 & 1.26 \\
\hline \multicolumn{4}{|c|}{ Equitability Index } & 0.93 & 0.95 \\
\hline \multicolumn{6}{|c|}{ FISH SPECIES } \\
\hline \multirow[t]{10}{*}{ Actinopteryg } & Clupidae & $\begin{array}{l}\text { Ethmalosa } \\
\text { fimbriata }\end{array}$ & Bonga shad & 58 & 9 \\
\hline & Mugilidae & Liza falcipinnis & Sicklefin mullet & 18 & 4 \\
\hline & Carangidae & Caranx hippos & Senegal jack & 6 & 7 \\
\hline & Bagridae & $\begin{array}{l}\text { Chrysichthys } \\
\text { nigrodigitatus }\end{array}$ & Bagrid catfish & 14 & 5 \\
\hline & Cichlidae & Tilapia guineensis & Guinean Tilapia & 11 & 6 \\
\hline & & $\begin{array}{l}\text { Sarotherodon } \\
\text { melanotheron }\end{array}$ & Black chin tilapia & 8 & 49 \\
\hline & & $\begin{array}{l}\text { Sarotherodon } \\
\text { galilae }\end{array}$ & Mango tilapia & 11 & 15 \\
\hline & Cynoglossidae & $\begin{array}{l}\text { Cynoglossus } \\
\text { senegalensis }\end{array}$ & Senegalese Tonguesole & 19 & 5 \\
\hline & Lutjanidae & Lutjanus agennes & African red snapper & 3 & 9 \\
\hline & Monodactylidae & e Psettias sebae & African moony & 5 & - \\
\hline \multicolumn{4}{|c|}{ Species Abundance } & 153 & 109 \\
\hline \multicolumn{4}{|c|}{ Species variety } & 10 & 9 \\
\hline \multicolumn{4}{|c|}{ Simpson's index 1-D } & 0.81 & 0.75 \\
\hline \multicolumn{4}{|c|}{ Shannon weiner index_H } & 1.95 & 1.78 \\
\hline \multicolumn{4}{|c|}{ Evenness_e $\mathrm{e}^{\wedge} \mathrm{H} / \mathrm{S}$} & 0.70 & 0.66 \\
\hline \multicolumn{4}{|c|}{ Margalef richness index } & 1.79 & 1.71 \\
\hline \multicolumn{4}{|c|}{ Equitability index } & 0.85 & 0.81 \\
\hline \multicolumn{4}{|c|}{ Menhinick Index } & 0.81 & 0.86 \\
\hline
\end{tabular}

Note: ref. site (ATMB) - Reference site (After Third Mainland Bridge) 
088 Nwabueze et al.: Physicochemical Characteristics, Animal Species Diversity and Oxidative Stress Responses
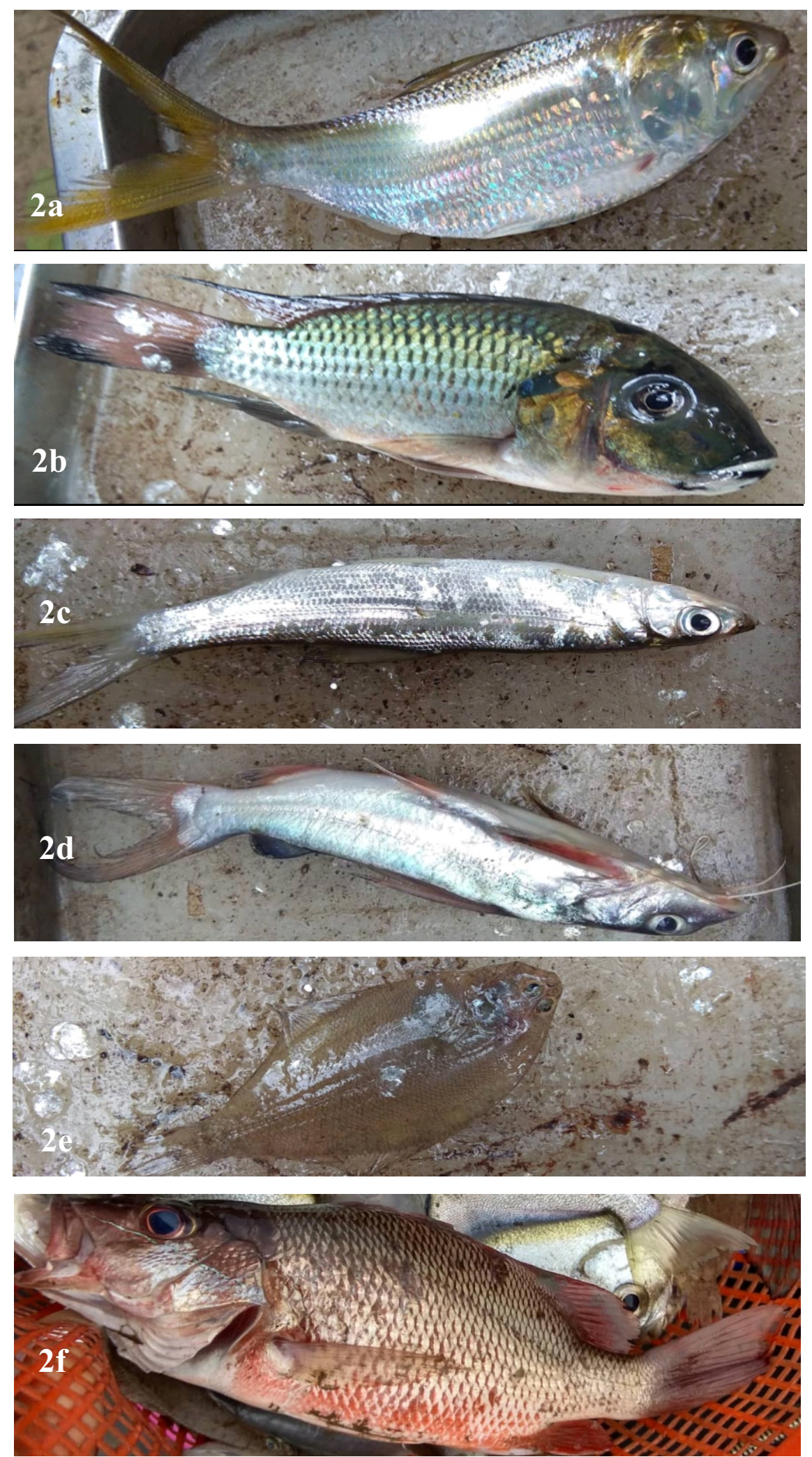

Plate 2a-f: Photographs of some fishes identified in this study. (2a) Ethmalosa fimbriata (Bonga shad), (2b) Sarotherodon melanotheron (Black chin tilapia), (2c) Liza falcipinnis (Sicklefin mullet), (2d) Chrysichthys nigrodigitatus (Bagrid catfish), (2e) Cynoglossus senegalensis (Senegalese Tonguesole), (2f) Lutjanus agennes (African red snapper) 
Biochemical Responses in the Gills and Liver of Dominant Fish Species at the Test (Iddo) and Reference (ATMB) Sites on the Lagos Lagoon, Nigeria

There was a significant $(\mathrm{p}<0.05)$ increase in the activity of SOD in the gills of E. fimbriata from the test site in July $(6.21 \pm 1.8 \mu \mathrm{mol} / \mathrm{ml} / \mathrm{mg}$ protein) and August $(4.19 \pm 0.8 \mu \mathrm{mol} / \mathrm{ml} / \mathrm{mg}$ protein) when compared with the fish from reference site (Table 3). Although there was no significant difference, activities of SOD in the gills of $E$. fimbriata was also higher in the month of September $(3.83 \pm 0.44 \mu \mathrm{mol} / \mathrm{ml} / \mathrm{mg}$ protein) than the reference site. CAT was significantly $(p<0.05)$ higher in E. fimbriata in the months of August $(17.79 \pm 4.6 \mu \mathrm{mol} / \mathrm{ml} / \mathrm{mg}$ protein) and September $(33.56 \pm 1.78 \mu \mathrm{mol} / \mathrm{ml} / \mathrm{mg}$ protein) than the activities in the fish from the reference site. It was also higher in E. fimbriata in July
(38.71 $\pm 1.05 \mu \mathrm{mol} / \mathrm{ml} / \mathrm{mg}$ protein). GSH concentration was higher in the gills of E. fimbriata in all of the three (3) months of this study, but there was significant difference $(p<0.05)$ in the month of July $(3.13 \pm 0.6 \mu \mathrm{mol} / \mathrm{ml})$ and September $(3.83 \pm 0.44 \mu \mathrm{mol} / \mathrm{ml})$. There was no significant difference $(\mathrm{p}>0.05)$ between the formation of MDA in the gills of E. fimbriata from the test site and $S$. melanotheron from the reference site. MDA was higher in gills of E. fimbriata in the test site in July $(1.41 \pm 0.1 \mu \mathrm{mol} / \mathrm{ml})$, August $(0.78 \pm 0.2 \mu \mathrm{mol} / \mathrm{ml})$, and September $(0.84 \pm 0.09$ $\mu \mathrm{mol} / \mathrm{ml}$ ) when compared to $S$. melanotheron from the reference site. Higher activity of GST was recorded in the gills of E. fimbriata than in $S$. melanotheron in all three months of this study, it was only significantly $(p<0.05)$ higher in the gills of $E$. fimbriata in the month of August (1.10 \pm 0.4 $\mu \mathrm{mol} / \mathrm{ml} / \mathrm{mg}$ protein) (Table 3).

Table 3: Biochemical responses in the Gills and Liver of Dominant Fish Species at the Test (Iddo) and Reference Sites on the Lagos lagoon, Nigeria

\begin{tabular}{|c|c|c|c|c|c|c|c|}
\hline Month & Site & Fish Species & GSH & SOD & CAT & MDA & GST \\
\hline \multicolumn{8}{|c|}{ GILLS } \\
\hline \multirow{2}{*}{ July } & Test & E. fimbriata & $3.13 \pm 0.6^{\mathrm{b}}$ & $6.21 \pm 1.8^{\mathrm{b}}$ & $38.71 \pm 1.05$ & $1.41 \pm 0.1$ & $3.04 \pm 0.33$ \\
\hline & Reference & S. melanotheron & $1.98 \pm 0.1^{\mathrm{a}}$ & $5.92 \pm 0.1^{\mathrm{a}}$ & $33.01 \pm 0.53$ & $0.44 \pm 0.7$ & $1.76 \pm 0.11$ \\
\hline \multirow{2}{*}{ August } & Test & E. fimbriata & $1.74 \pm 0.36$ & $4.19 \pm 0.8^{\mathrm{b}}$ & $17.79 \pm 4.6^{\mathrm{b}}$ & $0.78 \pm 0.2$ & $1.10 \pm 0.4^{\mathrm{b}}$ \\
\hline & Reference & S. melanotheron & $0.41 \pm 0.67$ & $1.42 \pm 0.07^{\mathrm{a}}$ & $11.07 \pm 0.17^{a}$ & $0.21 \pm 0.01$ & $0.41 \pm 0.07^{a}$ \\
\hline \multirow{2}{*}{ September } & Test & E. fimbriata & $3.83 \pm 0.44^{\mathrm{b}}$ & $3.83 \pm 0.44$ & $33.56 \pm 1.78^{\mathrm{b}}$ & $0.84 \pm 0.09$ & $2.75 \pm 0.18$ \\
\hline & Reference & S. melanotheron & $0.92 \pm 0.04^{\mathrm{a}}$ & $3.11 \pm 0.17$ & $17.30 \pm 0.37^{\mathrm{a}}$ & $0.29 \pm 0.01$ & $1.25 \pm 0.21$ \\
\hline \multicolumn{8}{|c|}{ LIVER } \\
\hline \multirow{2}{*}{ July } & Test & E. fimbriata & $5.44 \pm 0.31$ & $4.73 \pm 0.50$ & $39.26 \pm 4.56$ & $0.58 \pm 0.63$ & $2.65 \pm 0.36$ \\
\hline & Reference & S. melanotheron & $3.05 \pm 0.21$ & $4.00 \pm 0.80$ & $17.93 \pm 1.06$ & $0.54 \pm 0.21$ & $1.27 \pm 0.59$ \\
\hline \multirow{2}{*}{ August } & Test & E. fimbriata & $3.44 \pm 0.41^{\mathrm{b}}$ & $4.96 \pm 0.78$ & $25.41 \pm 3.26^{\mathrm{b}}$ & $0.53 \pm 0.06^{\mathrm{b}}$ & $1.57 \pm 0.08$ \\
\hline & Reference & S. melanotheron & $0.67 \pm 0.46^{a}$ & $1.83 \pm 0.05$ & $18.03 \pm 0.11^{a}$ & $0.23 \pm 0.01^{\mathrm{a}}$ & $0.62 \pm 0.4$ \\
\hline \multirow{2}{*}{ September } & Test & E. fimbriat a & $3.19 \pm 0.22$ & $5.93 \pm 0.62^{\mathrm{b}}$ & $31.60 \pm 1.87^{\mathrm{b}}$ & $0.72 \pm 0.17$ & $2.59 \pm 0.20$ \\
\hline & Reference & S. melanotheron & $2.46 \pm 0.19$ & $6.95 \pm 7.89^{a}$ & $16.36 \pm 0.41^{a}$ & $0.46 \pm 0.06$ & $2.05 \pm 0.26$ \\
\hline
\end{tabular}

Note: Biochemical activities (CAT, SOD, GST) were measured in $\mu \mathrm{mol} / \mathrm{ml} / \mathrm{mg}$ protein while GSH and MDA were measured in $\mu \mathrm{mol} / \mathrm{ml}$. Results are expressed as mean $\pm \mathrm{SD}, \mathrm{n}=3$. Dissimilar letters indicate significant difference of the parameter between the lagoons $(p<0.05)$, GSH - reduced glutathione, SOD - Superoxide dismutase, CAT - Catalase, MDA Malondialdehyde, GST-Glutathione-S-transferase. 
SOD levels recorded in the liver was significantly $(\mathrm{p}<0.05)$ lower in E. fimbriata $(5.93 \pm 0.62$ $\mu \mathrm{mol} / \mathrm{ml} / \mathrm{mg}$ protein) compared to $S$. melanotheron $(6.95 \pm 7.89 \mu \mathrm{mol} / \mathrm{ml} / \mathrm{mg}$ protein) in September, although SOD activity was higher in E. fimbriata in July $(4.73 \pm 0.50 \mu \mathrm{mol} / \mathrm{ml} / \mathrm{mg}$ protein) and August $(4.96 \pm 0.78 \mu \mathrm{mol} / \mathrm{ml} / \mathrm{mg}$ protein) than $S$. melanotheron. CAT activity recorded in the fishes was higher in E. fimbriata in July (39.26 \pm 4.56 $\mu \mathrm{mol} / \mathrm{ml} / \mathrm{mg}$ protein), August (25.41 \pm 3.26 $\mu \mathrm{mol} / \mathrm{ml} / \mathrm{mg}$ protein), and September (31.60 $\pm 1.87 \mu \mathrm{mol} / \mathrm{ml} / \mathrm{mg}$ protein), however, there was significant $(\mathrm{p}<0.05)$ increase in the month of August and September. GSH concentration in the liver of E. fimbriata was higher in all the months of this study compared to the GSH activities of the liver of S. melanotheron,

Also GSH levels in the liver of E. fimbriata $(3.44 \pm 0.41 \mu \mathrm{mol} / \mathrm{ml})$ was significantly higher $(\mathrm{p}<0.05)$ in August compared to $S$. melanotheron $(0.67 \pm 0.46 \mu \mathrm{mol} / \mathrm{ml})$ (Table 3). Lipid peroxidation (MDA) levels in the liver of $E$. fimbriata $(0.53 \pm 0.06 \mu \mathrm{mol} / \mathrm{ml})$ was significantly higher $(p<0.05)$ than $S$. melanotheron $(0.23 \pm 0.01$ $\mu \mathrm{mol} / \mathrm{ml}$ ) in August. MDA activity was also higher in the liver of $E$. fimbriata compared to $S$. melanotheron from July-September. GST activities measured in E. fimbriata from the test site in all three months were higher than in $S$. melanotheron from the reference site. There was no significant difference $(p>0.05)$ in the levels of GST in the livers of E. fimbriata and $S$. melanotheron in the course of this study (Table 3 ).

\section{DISCUSSION}

Surface water physicochemical parameters recorded in Iddo such as temperature, total dissolved solids, nitrates, phosphates and Biochemical Oxygen Demand (BOD) were within the regulatory limits of the Federal Ministry of Environment (FMEnv). The recorded temperature at the test and reference sites of the Lagos lagoon were within the same range as the finding of Amaeze et al. (2012). Also, Ayoola and Kuton (2009) recorded same range of temperature in the wet season as observed in this study. This is probably because temperature has been reported to be stable in the shallow brackish ecosystem of West Africa (Ayoola and Kuton, 2009). The Dissolved Oxygen (DO) and turbidity were higher than the set limit of FMEnv which could be attributed to the influx of fresh water from the Ogun River into the Lagos lagoon in the rainy season, and high intensity of rain in the months of sampling.

The low $\mathrm{pH}$ recorded in this study indicates acidity which may be due to acid rain which originates mainly from the release of gases into the atmosphere from the burning of oil, wastes and bushes (Bukola et al., 2015). Salinity recorded in this study was significantly $(\mathrm{p}<0.05)$ higher in the test area. Anthropogenic activities such as direct defaecation, direct untreated sewage discharge into the lagoon at the test site, direct public toilets channelled into the lagoon and solid waste dumps could be responsible for the high salinity recorded at the test site.

The reference area is a relatively uncontaminated area and therefore recorded lower salinity than the test site. Low salinity in the reference site could also be due to the influence of flooding from rainfall which results from the influx of fresh water from rivers surrounding the lagoon which mixes with saline water thereby diluting the salinity of lagoon water (Amaeze et al., 2012; Oluwajoba, 2017). Contamination was higher in the test site as observed in the higher values of physicochemical parameters (TDS, conductivity, nitrates, phosphates, BOD and COD) which were significantly higher than the reference site. The elevated level of COD of the test site is an indication that the sediments were affected by organic pollutants to an extent far greater than the reference site (Amaeze et al., 2012).

The overall species diversity (Shannon Weiner) and richness (Margalef) recorded in this study was generally low compared to the finding from earlier studies (Ajao and Fagade 1990) and falls within the range reported by Nkwoji (2016). Odum (1971) reported that species diversity tends to be low in disturbed ecosystems. From the benthic community structure of the test site, the low diversity and abundance recorded in this study is an indication that the test site area is a disturbed ecosystem due to the accumulation of contaminants from pre-historic and current anthropogenic activities (from the direct municipal waste discharge, effluents from 
industries, direct defecation into the lagoon, and leachates from dumps by the banks of the lagoon). The effect is shown in the high COD recorded in the area.

Macrobenthic invertebrates are sedentary in nature and are therefore vulnerable to impacts from environmental stressors. Hence, they are used as indicators of pollution (Yakub and Ugwumba, 2009). Most of the species of fishes recorded as occurring in the lagoon from this study is related to those reported by Oluwajoba et al. (2017). They reported that Ethmalosa fimbriata is a species that occurs throughout the year and could tolerate varying concentrations of salinity and other physical changes in the lagoon. The abundance of fish species recorded in this study is low when compared to the findings of other researchers: 24 species of 19 families was recorded by Amaeze et al. (2012) and Oluwajoba et al. (2017) reported 49 species. This could possibly be due to the fact that this sampling was done in the wet season. In the dry season, the level of water is lower which leads to increase in fish catch. Species of fishes are therefore more abundant in the dry season than in the wet season (Ayoola and Kotun, 2009). Most of the fish species caught in this study are majorly fishes reported by Oluwajoba et al. (2017) as occurring in the rainy season or throughout the year. Most of the fishes caught were tolerant species and therefore thrive in the area. Fishes were also more abundant in the test site because they feed on some of the organic pollutants such as faeces.

Bioindicators such as fish species are useful for detecting the presence and levels at which chemical pollution occurs in an environment (Olaniran et al., 2019). The aquatic environment is often used as sink for wastes which contaminates water bodies (Sogbanmu et al., 2019). Contaminants from these wastes can be absorbed by aquatic organisms through ingestion, dermal contact or through the gills and accumulates in tissues within the body. GSH and antioxidant enzymes are responsible for protection against reactive oxygen species (ROS) which cause oxidative stress (Athanasios et al., 2006). Increased levels of GSH in the gills and liver of E. fimbriata compared to $S$. melanotheron from the reference site could be for the sole reason of restoring balance from the damage caused by oxidative stress.

Although antioxidants are depleted in cells when exposed to pollutants, levels of GSH in living systems can increase in order to restore the imbalance from oxidative damage which can lead to the activation of expressions of genes encoding antioxidants (Arojojoye and Adeosun, 2016). SOD helps break down potentially harmful oxygen molecules in cells, thereby preventing damage to tissues. Increase in the activities of superoxide dismutase in the month of July and August, suggests the induction of the enzyme. Significantly decreased levels of SOD observed in the liver of E. fimbriata compared to S. melanotheron in the month of September could be due to the overproduction of superoxide radicals. The enzyme might have been overwhelmed by contaminants from the test site and could no longer protect cells against superoxide radicals (Arojojoye and Adeosun 2016).

CAT is a heme enzyme present in the peroxisomes of cells of most living organisms. It mitigates the toxic effects of hydrogen peroxide $\left(\mathrm{H}_{2} \mathrm{O}_{2}\right)$ in cells where they are produced by metabolizing it into water and oxygen (Arojojoye and Adeosun 2016). Increased levels of GST and CAT recorded in E. fimbriata than in $S$. melanotheron shows an induction of the enzymes in response to the contaminated environment. Lipid peroxidation is the metabolic process whereby ROS results in oxidative deterioration of lipids of cell membranes. The increased levels of MDA in the gills and liver of $E$. fimbriata in comparison to $S$. melanotheron from the reference site indicates induction of lipid peroxidation.

The levels of MDA in the gills were higher than the in the liver tissue. Gills are the most affected among other tissues in fishes because they are the first to come in contact with contaminants in the aquatic environment and they exhibit low threshold response to oxidative stress from waterborne contaminants (Borkovic et al., 2008). High levels of MDA have been reported in fishes from the Asejire River in Oyo State by Arojojoye, and Adeosun (2016).

\section{CONCLUSION}

The results obtained from this study showed the 
092 Nwabueze et al.: Physicochemical Characteristics, Animal Species Diversity and Oxidative Stress Responses

fairly stressed nature of the test site (Iddo) on the Lagos lagoon evidenced by poor water quality based on the surface water and sediments' physicochemical parameters, low macrobenthic invertebrate species diversity, though with a high fish species diversity. Variations of the oxidative stress indices in gills and livers of the two dominant fish species from the study areas indicate that the fishes from the test site were under oxidative stress from contaminants the lagoon receives. Hence, there is the need for constant monitoring of the water quality to detect deviation from the normal status such that if there is a marked difference from previous status, it can serve as an early warning signal before adverse effects are observed, given the benefits of the lagoon ecosystem. Environmental Regulatory Agencies should also enforce stringent environmental regulations and laws to hinder or restrict pollution of the lagoon from unregulated anthropogenic activities in order to support the achievement of the United Nations Sustainable Development Goal 14 (life below water).

\section{ACKNOWLEDGEMENT}

The authors are thankful to the Department of Zoology, Faculty of Science, University of Lagos, Akoka, Lagos, Nigeria, for their support with life jackets, chemicals, Horiba U-10 and motorized boat.

\section{DECLARATION OF INTEREST}

The authors declare no conflict of interest.

\section{REFERENCES}

Ajagbe, F. E., Osibona, A.O. and Otitoloju A. A. (2012). Diversity of the edible fishes of the Lagos Lagoon, Nigeria and the public health concerns based on their Lead $(\mathrm{Pb})$ content. International Journal of Fisheries and Aquaculture, 2(3): 55-62.

Ajao, E.A. and Fagade, S.O. 1990. A study of the sediments and communities in Lagos Lagoon, Nigeria. Oil and Chemical Pollution, 7: 85-117.

Alava, J.J., Cheung, W.W.L., Ross, P.S. and Sumaila, U.R. 2017. Climate change-contaminant interactions in marine food webs: Towards a conceptual framework. Global Change Biology, 23: 3984-4001.

Alexander, T.J., Vonlanthen, P. and Seehausen, O.
2017. Does eutrophication-driven evolution change aquatic ecosystems? Philosophical Transactions of the Royal Society of London, Series B, 372: 20160041.

Amaeze, N.H., Egonmwan, R.I., Jolaoso, A.F. and Otitoloju, A.A. 2012. Coastal environmental pollution and fish species diversity in Lagos Lagoon, Nigeria. International Journal of Environmental Protection, 2(11): 8-16.

Arojojoye, O.A. and Adeosun, A.M. 2016. Effect of environmental pollution on oxidative stress biomarkers in African Catfish (Clarias gariepinus) from Asejire River in Oyo State, Nigeria. Journal of Environmental and Occupational Science, 5(4): 71.

Athanasios, V., Thomais V., Manos D. and Michael, S. 2006. Molecular biomarkers of oxidative stress in aquatic organisms in relation to toxic environmental pollutants. Ecotoxicology and Environmental Safety, 64: 178-189.

AVMA (American Veterinary Medical Association), 2013. AVMA Guidelines for the euthanasia of animals. 2013 edition pg. 70. 102pp.

Ayoola, S.O. and Kotun, M.P. 2009. Seasonal variation in fish abundance and physicochemical parameters of Lagos lagoon, Nigeria. Journal of Environmental Science and Technology, 3(5): 149-156.

Birben, E., Sahiner, U. M., Sackesen, C., Erzurum, S. and Kalayci, O. 2012. Oxidative stress and antioxidant defense. The World Allergy Organization Journal, 5(1):9-19.

Buege, J. A. and Aust S. D. 1978. Microsomal lipid peroxidation. Methods in Enzymology, 52: 302-310.

Bukola, D., Zaid A., Olalekan, E. I. and Falilu, A, 2015. Consequences of anthropogenic activities on fish and the aquatic environment. Journal of Poultry, Fisheries and Wildlife Sciences, 3: 138.

Emmanuel, B.E., Chukwu, L.O. and Bakare, S.O. 2010. Hydro-chemistry, macroinvertebrate fauna and fish production of Acadja fishing site in a Tropical Lagoon Ecosystem. The Journal American Science, 61: 42-48.

Habig, W.H., Pabst, M.J. and Jakoby, W.B. 1974. Glutathione S-transferases the first enzymatic step in mercapturic acid 
formation. The Journal of Biological Chemistry, 249(22): 7130-7139.

Hammer, Ø., Harper, D. and Ryan, P. 2001. PAST: Palaeontological statistics software package for education and data analysis. Palaeontologia Electronica, 4: 1-9.

Kane, S., Qarri, F., Lazo, P. and Bekteshi, L. 2015. The effect of physico-chemical parameters and nutrients on fish growth in Narta Lagoon, Albania. Journal of Hygienic Engineering and Design, 639:32-496.

Lawson, E.O. 2011. Physico-chemical parameters and heavy metal contents of water from the mangrove swamps of Lagos Lagoon, Lagos, Nigeria. Advances in Biological Research, 5(1): 8-21.

Magwere, T., Naik, Y.S., Hasler, Y.S. 1997. Effects of chloroquine treatment on antioxidant enzymes in rat liver and kidney. Free Radical Biology and Medicine, 22(1-2): 321-327.

Nkwoji, J.A. 2016. Impact of hypoxia on the community structure of benthic macroinvertebrates of Lagos lagoon, Nigeria. Journal of Applied Sciences and Environmental Management, 20(1): 121-130.

Odum, E.P. 1971. Fundamentals of Ecology. 3rd Ed., Philadelphia: W.B. Suanders Company.

Olaniran, E.I., Sogbanmu, T.O. and Saliu, J.K. 2019. Biomonitoring, physico-chemical and biomarker evaluations of abattoir effluent discharges into the Ogun River from Kara Market, Ogun State, Nigeria using Clarias gariepinus. Environmental Monitoring and Assessment, 191: 44.

Oluwajoba, E.O., Fakayode, O.S., Oluboba, T.F., Williams, A.B., Ukaonu, S.U., FolaMatthews, O.O. 2017. Seasonal variation in species abundance, diversity and composition of fish fauna in Lagos Lagoon, Nigeria. Nigeria Journal of Fisheries, 14:1281-1288.

Sedlak, J. and Lindsay, R.H. 1968. Estimation of total, protein-bound, and nonprotein sulfhydryl groups in tissue with Ellman's reagent. Analytical Biochemistry, 25: 1192-1205.

Shannon, C.E., and Weaver, W. 1949. The Mathematical Theory of Communication. Urbana, Illinois: University of Illinois Press; 125pp.

Singh, J., Hewawassam, H. and Moffat, D. 1995. Nigeria: Strategic options for redressing industrial pollution. Industry and Energy Division, West Central Africa Department 1:45.

Sinha, K.A. 1972. Colometric assay of catalase. Analytical Biochemistry, 47:389-394.

Sogbanmu, T.O., Osibona, A.O., Oguntunde A.O. and Otitoloju, A.A. 2018. Biomarkers of toxicity in Clarias gariepinus exposed to sublethal concentrations of polycyclic aromatic hydrocarbons. African Journal of Aquatic Science, 43(3): 281-292.

Sogbanmu, T.O., Osibona, A.O. and Otitoloju, A.A. 2019. Specific polycyclic aromatic hydrocarbons identified as ecological risk factors in the Lagos lagoon, Nigeria. Environmental Pollution, 255:113295

Sogbanmu, T.O., Fatunsin, O.T., Echebiri, F.O., Otitoloju, A.A. and Olayinka, K.O. (2020). Sawmill activities near the Lagos lagoon, Nigeria: Polycyclic aromatic hydrocarbons analysis and embryotoxic evaluations of sediment extracts using Clarias gariepinus. Bulletin of Environmental Contamination and Toxicology, 104(6): 809-819

Yakub, A.S. and Ugwumba, A.A.A. 2009. A study on macroinvertebrate fauna of Lower Ogun River at Ishasi, Ogun State, Southwest Nigeria. The Zoologist, 7: 65-74.

Yankson, K. and Kendall, M.A. 2001. A student's guide to the seashore of West Africa: Marine biodiversity capacity building in the West African sub-region. 132pp. 